\title{
Nutritive Analysis of Cicer Arietinum Via Colorimetery
}

\author{
D. Geetha, M. S. Revathy, Gangadhara Angajala, P. Manorama, L. Sudha
}

\begin{abstract}
The seeds of cicerarietinum were made into flour, cooked in a different methods and analyzed for Phosphorous, Phytin, Ionisable Iron, Niacin and Thiamin by standard methods.Nutritious values of cicerarietinum varies significantly when they cooked. Mode of cooking play a vital role in the determination of nutrition in food. Gram flour has significant amounts of niacin and thiamin and ionisable iron in its uncooked flour form.This flour have $280 \mathrm{mg} / 100 \mathrm{~g}$ phosphorous, 1.6 $\mathrm{mg} / 100 \mathrm{~g}$ ionisable iron, $0.357 \mathrm{mg} / 100 \mathrm{~g}$ thiamin and $4.7 \mathrm{mg} / 100 \mathrm{~g}$ niacin. Thus, the flour may be used as value addition food which in turn increased nutrition in low cost.
\end{abstract}

\section{Keywords : Microwave cooking; Thiamin; Niacin}

\section{INTRODUCTION}

CicerArietinum (Bengal gram, chickpea) is one among the important pulse crops grown and used as important food acrossthe world. It has significant nutrients like carbohydrates and protein, vitamins and mineral.CicerArietinum is the principal food legume in India. Generally vegetable proteins especially from pulses are considered to be of an inferior quality as compared to that of the animal proteins due to the deficiency of two essential amino acids, viz., methionine and tryptophan $[1,2]$. Though the protein quality in bengal gram is considered to be better than other pulses, the reason for low consumption of CicerArietinumis given below in Figure 1 [1]. In addition to that the polyphenols present in pulses interfere with the assimilation of proteins [1]. Even though India is the largest producer of chickpea, it still imports chickpea from other countries because, of the food value. Keeping in view, the ever-increasing demand for this legume crops, it is essential to improve the production and analyze the nutritional values under different cooking pattern. The nutritive sources, minerals are essential for fighting malnutrition which have been the biggest challenge of the developing countries. To fight with the protein deficiency diseases such as Kwashiorkor, imbalance diet, proteins from

\footnotetext{
Revised Manuscript Received on December 09, 2019.

* Correspondence Author

D.Geetha*, Chemistry, Kalasalingam Academy of Research and Education, Krishnankoil, Virudhunagar, India. Email: geethachem2015@gmail.com

M.S.Revathy, Physics, Kalasalingam Academy of Research and Education, Krishnankoil, Virudhunagar, India. Email: revz.vijay@gmail.com

Gangadhara Angajala, Chemistry, Kalasalingam Academy of Research and Education, Krishnankoil, Virudhunagar, India. Email: gangadharaangajala@gmail.com

P. Manorama , Chemistry, Kalasalingam Academy of Research and Education, Krishnankoil, Virudhunagar, India. Email: manorama.p.jeyarajam@gmail.com

L.Sudha, Chemistry, Kalasalingam Academy of Research and Education, Krishnankoil, Virudhunagar, India. Email lakshmi16narayanan@gmail.com
}

pulses are essential. The continuous researches on Bengal gram revealed that, it contains total carbohydrates 52.4 to $70.9 \%$ [1], having good nutritive values viz ash content, moisture content, total carbohydrate, calcium, protein and other essential amino acids. In developing countries like India, cultivation of pulses like Bengal gram is the quickest way to augment the production of food proteins [1,2-6].

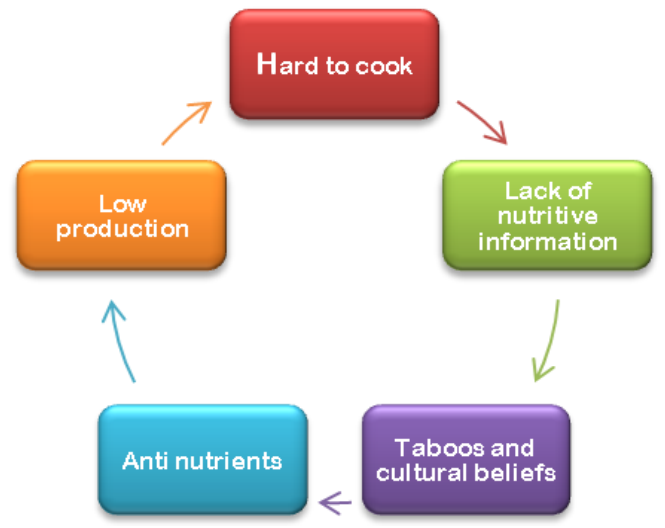

Fig. 1. Reason for lower consumption of Cicer Arietinum
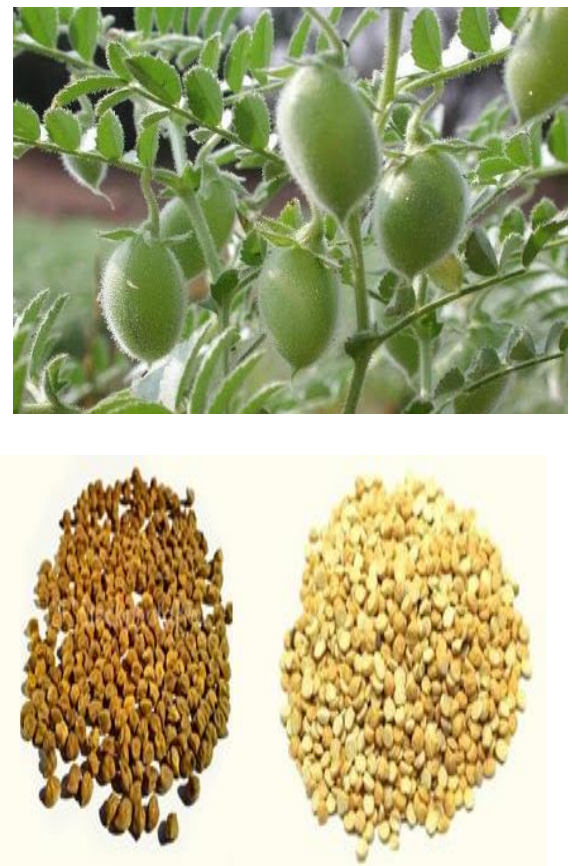

Fig. 2. Cicer Arietinum plant, raw seeds and broken pulses 
The purpose of the present investigation is to study the nutritional quality of Cicer Arietinum in terms of phosphorous, ionisable iron, phosphorous in phytinform, vitamin B1 and vitamin B6.

\section{MATERIALS AND METHODS}

The seeds of CicerArietinum varieties were procured from local shops in Krishnan Koil.Samples for the present analysis were prepared as follows [3]:CicerAritinumseeds soaked in distilled water $(1: 10, \mathrm{w} / \mathrm{v})$ for $8 \mathrm{hrs}$, at room temperature $(\sim 25$ $\left.{ }^{\circ} \mathrm{C}\right)$. The soaked seeds were drainedand divided into three parts for cooking according to Alajaji and EL-Adawy (2006) and Helmy (2003b).

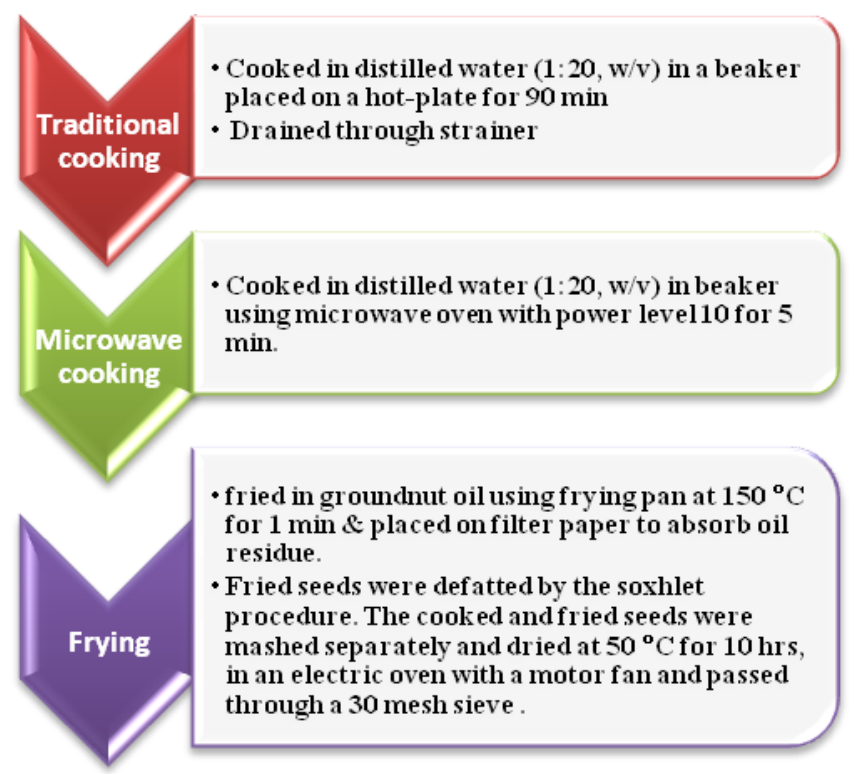

Fig. 3. Methodologies adopted for cooking Bengal gram

Minerals determination: Mineral contents, i.e. phosphorous $(\mathrm{P})$, ionisableiron $(\mathrm{Fe})$, phytin phosphorous, niacin and thiamin were determined according to the prescribed methods using colorimeter as follows:

\section{- Estimation of Phosphorous}

The solution of Bengal gram flour is treated with an acid molybdenate reagent, which reacts with inorganic phosphate to form phosphor-molybdic acid. The hexavalent molybdenum of the phosphor-molybdic acid is reduced to give a blue compound which is estimated colorimetrically.

\section{- Estimation of Ionisable Iron}

The sample of Bengal gram (5g) was taken into a boiling test tube and mixed with $50 \mathrm{ml}$ of water, boiled for half-an-hour in a boiling water bath, centrifuged and added 10 $\mathrm{ml}$ of $10 \%$ trichloro acetic acid to the supernatant. Centrifuged and filtered. This is the experimental solution. Then pipette out standard iron solution ranging from $0.1 \mathrm{ml}$ to $0.5 \mathrm{ml}$ with their corresponding $\mathrm{r}$ values of 10 to 50 $\mathrm{r}$ into a series of test tubes.Added $0.3 \mathrm{ml}$ of concentrated sulphuric acid, $0.4 \mathrm{ml}$ of standard potassium persulphate and $1.6 \mathrm{ml}$ of $3 \mathrm{~N}$ potassium thiocyanate. Made up the volume to $10 \mathrm{ml}$ with water.Taken $5.0 \mathrm{ml}$ of the test solution and treated similarly. The color developed was read at $540 \mathrm{~m}$. $\mu$ within 20 minutes.

\section{- Estimation of Phytin phosphorous}

Phytin phosphorous was estimated bythiocyanate method. The added ferric chloride forms a complex of phytic acid -ferric ion which is insoluble. The excess ferric ion remaining in the solution is estimated by thiocyanide method.

\section{- Estimation of Niacin}

Niacin present in Bengal gram reacts with cyanogens bromide to give a pyridinium compound which undergoes rearrangement yielding a detivative that will couple with aromatic amines giving colored compounds under proper condition, the intensity of the color produced is proportional to the amount of niacin present and can be measured colorimetrically.

\section{- Estimation of Thiamin}

Thiamin is estimated using ferri-cyanide solution for that $5.0 \mathrm{gm}$ of the powdered sample taken in two conical flasks. Added $50 \mathrm{ml}$ of $2 \%$ acetic acid to each of the flask. Congo red was used as an indicator.

\section{RESULTS AND DISCUSSION}

Data showed that major minerals phosphorous, phytin phosphorous and minor elements ionisable iron were detected in raw Bengal gram flour at higher levels as compared to that of the cooked flours. As per the results given in Table I, the cooking treatments caused a decrease in phosphorous, ionisable iron, phytin phosphorous, vitamins like thiamin and niacin might be attributed to their diffusion into cooking water. These results are in agreement with those obtained by Esmat et al., (2010). The main objective of this work is to compare the nutritional values of raw pulse flour with those of differently cooked flours. The results of this work suggested that raw Bengal gram flour have good source vitamins (B1 and B3) and minerals (phosphorous, ionisable iron). Moreover, new methods have been analyzed for the determination of vitamins and minerals work well and the results correlate well with that of AOCS methods of analysis of food [7-9].

\section{Estimation of phosphorous}

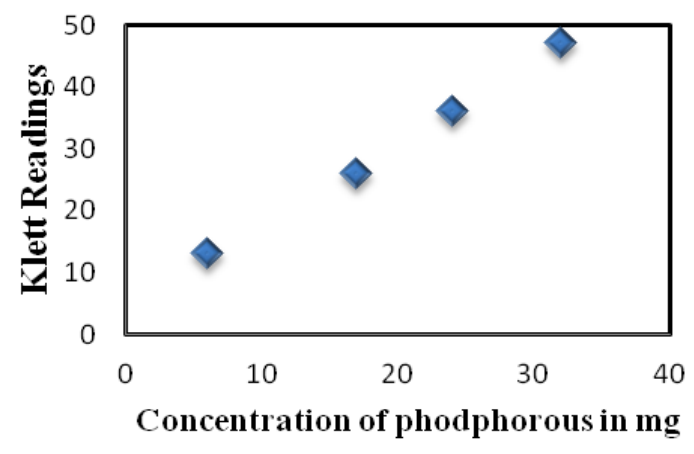

Fig. 4. Calibration graph for the colorimetric estimation of phosphorous. 


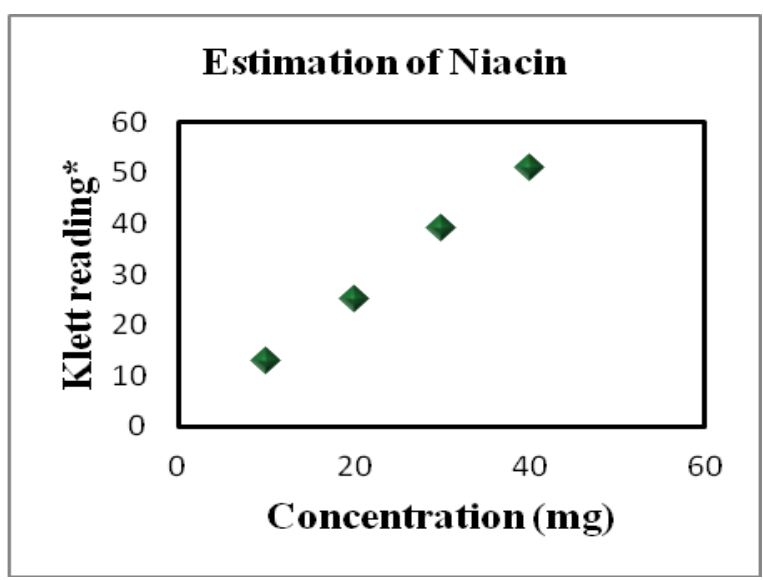

Fig. 5. Calibration graph for the colorimetric estimation of niacin * Klett reading corresponds to $23 \mu$.gm of niacin.

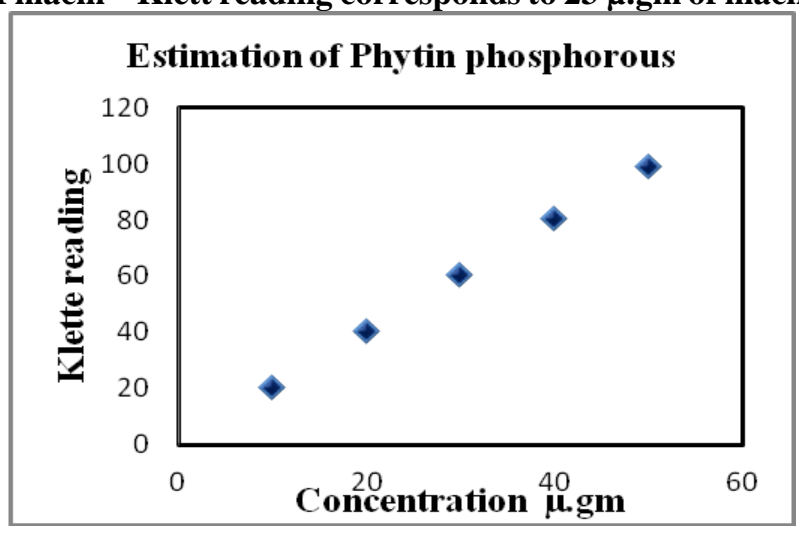

Fig. 6. Calibration graph for the colorimetric estimation of phytin phosphorous.

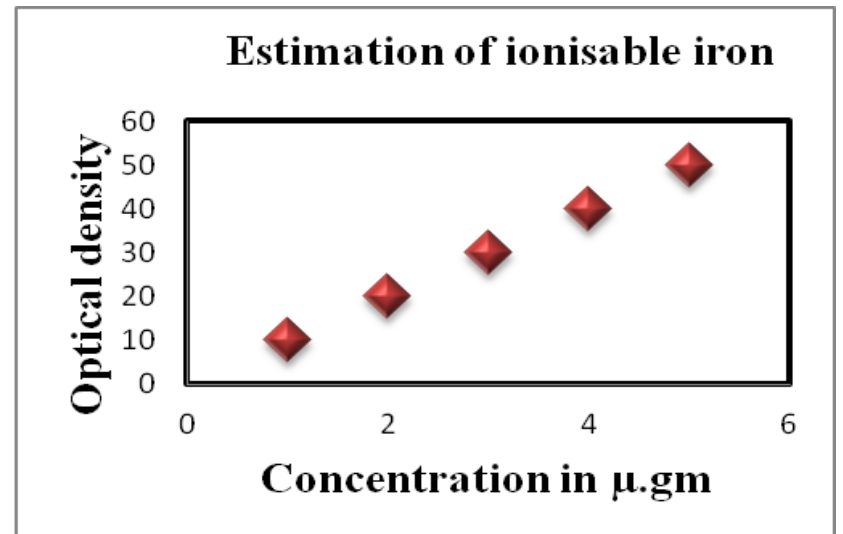

Fig. 7. Calibration graph for the colorimetric estimation of ionisable iron.

Table I: Nutritive analysis report

\begin{tabular}{|c|c|c|c|c|}
\hline \multirow{2}{*}{$\begin{array}{c}\text { Nutrients } \\
\text { Minerals/ } \\
\text { Vitamins }\end{array}$} & Raw & $\begin{array}{c}\text { Cooke } \\
\mathbf{d} \\
\text { (Traditio } \\
\text { nally) }\end{array}$ & $\begin{array}{c}\text { Cooke } \\
\text { d } \\
\text { (Microwa } \\
\text { ve) }\end{array}$ & Fried \\
\hline $\begin{array}{c}\text { Phytin } \\
\text { (mg/100 g) }\end{array}$ & 125 & 103 & 113 & 97 \\
\hline $\begin{array}{c}\text { Phosphorous } \\
(\mathrm{mg} / 100 \mathrm{~g})\end{array}$ & 280.2 & 209.20 & 230.58 & 188.42 \\
\hline $\begin{array}{c}\text { Ionisable Iron } \\
(\mathrm{mg} / 100 \mathrm{~g})\end{array}$ & 1.60 & - & 1.20 & - \\
\hline $\begin{array}{c}\text { Thiamin } \\
(\mathrm{mg} / 100 \mathrm{~g})\end{array}$ & 0.357 & - & - & - \\
\hline $\begin{array}{c}\text { Niacin } \\
(\mathrm{mg} / 100 \mathrm{~g})\end{array}$ & 4.7 & 2.1 & 2.9 & - \\
\hline
\end{tabular}

The colorimetric estimation acts as a very good tool in determining the minerals and vitamins of the pulses. The nutritive values viz. phosphorous, ionisable iron, niacin and thiamin of Cicer Arietinum highly affected by various cooking methods. All the values of functional properties for microwave cooking flour were high compared with those of other cooking methods through colorimetric method of analysis.

\section{REFERENCES}

1. BenuSinghai, and S. K. Shrivastava, "Nutritive value of new chickpea (Cicer arietinum) varieties Journal of Food," Agriculture \& Environment.,Vol.4 (1), 2006, pp.48-53.

2. HarshaHirdyani,"Nutritional composition of Chickpea (Cicerarietinum-L) and value added products, ” Indian Journal Of Community Health., vol 26, 2014, pp.202-206.

3. A. Esmat, Abou Arab*, I. M. F. Helmy, and G. F. Bareh, "Nutritional Evaluation and Functional Properties of Chickpea (Cicerarietinum L.) Flour and the Improvement of Spaghetti Produced from its," Journal of American Science., Vol.6 (10), 2010, pp.1055-1072.

4. K. O. Adebowale, and O. S. Lawal, "Comparative study of the functional properties of bambara groundnut (Voandzeiasubterra-nean). Jack bean (canavaliaensiformis) and mucunabean (mucunapruriens) flours," Food Research International, 37, 355365.2004

5. N. Khatoon, and J. Prakash, "Nutritional quality of microwavecooked and pressurecooked legumes, " International Journal of Food Sciences and Nutrition ., Vol.55, 2004, pp.441-448.

6. W. Guo, G. Tiwari, J. Tang, and S. Wang, "Frequency, moisture and temperature dependent dielectric properties of chickpea flour," Biosystems Engineering., Vol.101, 2008, pp.217-224.

7. O. Ngozi Kabuo, A. Sunday Dialoke, C. Gloria Omeire, N. Evelyn Bedi, I. Ann Peter-Ikechukwu, and E. ThankGod Irekpita, "Comparison of Proximate Composition of Some Cultivars of Chickpea (Cicerarietinum L.) Cultivated in Owerri," Food Science and Quality Management., Vol. 37, 2015, pp.105-109.

8. J. K. Pittaway, I. K. Robertson, M. J. Ball, "Chickpeas may influence fatty acid and fibre intake in an ad libitum diet, leading to small improvements in serum lipid profile and glycemic control," Journal of the American Dietetic Association., Vol. 108 (6), 2008, pp.1009-1013.

9. A. Clemente, J. Vioque, R. Sanchez Vioque, J. Pedroche, J. Bautista and F. Millan, "Factors affecting the in vitro protein digestibility of chickpea albumins," Journal of the Science of Food and Agriculture., Vol. 80, 2000, pp. 79-84.

\section{AUTHORS PROFILE}

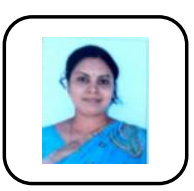

D.Geetha has completed M. Sc in Chemistry discipline from Bharathidasan University, M. Phil., from Annamalai University. She completed Ph. D from Jaypee University in 2016. She is currently working as an Assistant professor at Kalasalingam Academy of Research and Education from 2017 onwards. Her field of interest is bio surfactant. She has published 7 papers in reputed international journals.

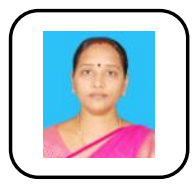

M.S.Revathy, has completed her Ph.D in Anna University in 2016. She has done M.Sc., M.Phil Physics in Mother Teresa Women's University, Kodaikanal. Currently working as Assistant Professor in Department of Physics, Kalasalingam Academy of Research and Education and her field of interests are thin films and green synthesis of nanomaterials. She has published 6 papers in international journals.

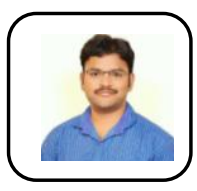

Gangadhara Angajala is working as an Assistan professor in Department of Chemistry at Kalasalingam Academy of Research and Education. He completed his under-graduation in

B.Sc with triple major at

Government Degree College for Men,

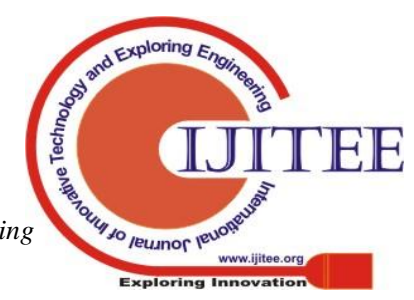


Anantapur, Andhra pradesh and his graduation with specialization in Pharmaceutical Chemistry at Vellore Institute of Technology, Tamil nadu. He obtained his Ph.D with specialization in Organic and Medicinal Chemistry from Vellore Institute of Technology. His research area includes synthesis of new quinoline scaffolds with hypoglycemic efficacy by using nanocatalysis.

P. Manorama has completed her B. Sc Chemistry from Holy Cross College, Trichy and M. Sc from Avinashi Lingam College, Coimbatore. She has completed M. Phil from Madurai Kamarajar University. Currently she is a research scholar in the Department of chemistry, Kalasalingam Academy of Research and Education. Her research interest is in phytochemistry.

Mrs. Sudha Lakshminarayanan her B.Sc and M.Sc in chemistry from the Sri Paramakalyani College, Alwarkuruchi and M.Phil in Bharathidasan University, Trichy, India. Presently, she is working as Assistant Professor at JP College of Arts and Science, Agarakattu, Tamilnadu. She is pursuing doctoral degree in Chemistry at Kalasalingam Academy of Research and Eucation(KARE) under the guidance of Dr. Geetha Das and Dr. Selvapalam. She has research interest on Host-guest chemistry. She has published over 5 research article in reputed international journals. 